\title{
PENGARUH PROMOSI KESEHATAN TENTANG IMUNISASI PADA ANAK USIA 0-5 TAHUN TERHADAP PENINGKATAN PENGETAHUAN IBU DI PUSKESMAS SENTANI
}

\author{
Natalia Lisma Br Sembiring ${ }^{1}$, Vivi Hermalina Barends², Enos Supriyanto \\ ${ }^{1)}$ Program Studi S1 Keperawatan STIKES Jayapura \\ ${ }^{2)}$ Mahasiswa Prodi S1 Keperawatan STIKES Jayapura \\ ${ }^{3)}$ Rumah Sakit Umum Daerah Kwaingga Kabupaten Keerom \\ Email: lisma.natalies@gmail.com
}

\begin{abstract}
ABSTRAK
Latar belakang: Promosi kesehatan tidak hanya proses penyadaran masyarakat atau pemberian dan peningkatan pengetahuan masyarakat tentang kesehatan saja, tetapi disertai dengan upaya-upaya memfasilitasi perubahan perilaku. Peran perawat berdasarkan UU RI Nomor 38 tahun 2014, sebagai penyuluh dan konselor, melakukan pengkajian keperawatan secara holistik ditingkat individu dan keluarga serta ditingkat kelompok dan masyarakat, melakukan pemberdayaan masyarakat, melaksanakan advokasi dalam perawatan pelayanan kesehatan masyarakat, menjalin kemitraan dalam perawatan kesehatan masyarakat dan melakukan penyuluhan kesehatan dan konseling. Tujuan: Untuk mengetahui apakah ada pengaruh promosi kesehatan tentang imunisasi pada anak usia 0-5 tahun terhadap peningkatan pengetahuan ibu di Puskesmas Sentani. Jenis Penelitian: Menggunakan jenis penelitian kuantitatif dengan rancangan PraEksperimen (pra-experiments design) dengan One group Pretest-Postest. Populasi dalam penelitian ini sebanyak 1.347 orang ) dengan jumlah sampel sebanyak 93 responden yang diambil dengan menggunakan teknik accidental sampling. Hasil: Uji paired sample T-Test sebesar -10.869 sehingga bisa diambil kesimpulan untuk menerima $\mathrm{H}_{\mathrm{a}}$ karena $\mathrm{p}$ value $<\alpha$ yaitu $0,000<0,05$. Kesimpulan: Terdapat pengaruh promosi kesehatan tentang imunisasi pada anak usia 0-5 tahun terhadap peningkatan pengetahuan ibu di Puskesmas Sentani.
\end{abstract}

Kata kunci: Promosi Kesehatan, Imunisasi, Anak, Pengetahuan

\begin{abstract}
Background: Health promotion is not only a process of public awareness or giving and increasing public knowledge about health, but is accompanied by efforts to facilitate behavioral change. The role of nurses based on RI Law No. 38 of 2014, as counselors and counselors, conduct nursing studies holistically at the individual and family level and at the group and community level, conduct community empowerment, carry out advocacy in the care of public health services, establish partnerships in community health care and conduct health counseling and counseling. Objective: To find out whether there is an effect of health promotion on immunization in children aged 0-5 years to increase maternal knowledge in Sentani Health Center. Research Type: Using quantitative research with pre-experiment design with One group PretestPostest. The population in this study was 1,347 people) with a total sample of 93 respondents taken using accidental sampling technique. Results: Paired sample T-Test of -10,869 so that conclusions can be drawn to accept Ha because the $p$ value $<\alpha$ is $0,000<0.05$. Conclusion: There is an effect of health promotion about immunization in children aged 0-5 years to increase maternal knowledge in Puskesmas Sentani.
\end{abstract}

Keywords: Health Promotion, Immunization, Children, Knowledge 


\section{PENDAHULUAN}

World Health Organization (WHO) pada tahun 1984, merevitalisasi devisi pendidikan kesehatan (Health Education) berubah menjadi istilah promosi kesehatan. Promosi kesehatan sebagai "The Process of enabling individuals and communtes to increase control over the determinants of health and thereby improve their health". Promosi kesehatan tidak hanya proses penyadaran masyarakat atau pemberian dan peningkatan pengetahuan masyarakat tentang kesehatan saja, tetapi disertai dengan upaya-upaya memfasilitasi perubahan perilaku. Promosi kesehatan bertujuan untuk meningkatkan kemampuan individu, keluarga, kelompok dan masyarakat untuk hidup sehat (Sinta, 2011).

Sebagaimana tercantum dalam Keputusan

Menteri Kesehatan Nomor
1114/MENKES/SK/VII/2005 tentang Pedoman Pelaksanaan Promosi Kesehatan untuk meningkatkan kemampuan masyarakat melalui pembelajaran dari, oleh, untuk dan bersama masyarakat, agar mereka dapat menolong diri sendiri, serta mengembangkan kegiatan yang bersumber daya masyarakat, sesuai sosial budaya setempat dan didukung kebijakan publik (Kemenkes, 2011).

Promosi kesehatan adalah upaya pemberdayaan masyarakat yang mampu memecahkan dan meningkatkan kesehatan. Peran perawat berdasarkan UU RI Nomor 38 tahun 2014, sebagai penyuluh dan konselor, melakukan pengkajian keperawatan secara holistik ditingkat individu dan keluarga serta ditingkat kelompok dan masyarakat, melakukan pemberdayaan, melaksanakan advokasi dalam perawatan pelayanan kesehatan, menjalin kemitraan dalam perawatan kesehatan dan melakukan penyuluhan kesehatan dan konseling (Kian Santang, 2018).

Laporan UNICEF yang dikeluarkan terakhir menyebutkan bahwa 27 juta anak balita di seluruh dunia masih belum mendapatkan pelayanan imunisasi secara rutin. Akibatnya, penyakit yang dapat dicegah oleh vaksin ini diperkirakan menyebabkan lebih dari dua juta kematian terjadi setiap tahun (Nurul, 2017).

Menurut data Depkes tahun 2013, upaya imunisasi terbukti berhasil menurunkan angka kematian dan angka kesakitan bayi dan balita yang disebabkan oleh penyakit dapat dicegah dengan imunisasi. Namun, keberhasilan dari program imunisasi dipengaruhi oleh tingkat pengetahuan ibu tentang imunisasi karena dengan pengetahuan tersebut dapat mempengaruhi ibu untuk mengimunisasikan anaknya (Dwi, 2017).

Cakupan Imunisasi Dasar Lengkap (IDL) di Indonesia tahun 2016 belum mencapai target. Pemerintah menargetkan cakupan IDL sebesar 91,5\%, namun hingga akhir tahun hanya $82,1 \%$ yang berhasil tercapai. Angka tersebut setara 3.589.226 bayi yang lahir sepanjang 2016 . Capaian 2016 berbeda dengan 2015 yang berhasil melebihi target. Cakupan IDL mencapai 80\%, yang lebih besar dari target sebesar $75 \%$, angka tersebut setara 4.139 .903 bayi yang lahir setahun kemarin (Nurul, 2017).

Rata-rata imunisasi di Indonesia pada tahun 2017, BCG 89,1\%, Hb0 86,6\%, DPT-HbHib1 90,7\%, DPT-Hb-Hib3 88,3\%, polio4 86,8\%, Campak/MR1 89,8\%, IPV 41,5\% (Kemenkes RI, 2017).

Sasaran imunisasi di Indonesia sebanyak 19 Provinsi (56\%) telah mencapai minimal 80\% sasaran bayinya mendapatkan imunisasi dasar lengkap. Namun sebanyak 2 provinsi hanya mencapai imunisasi dasar lengkap $<60 \%$, yaitu Papua $(47,3 \%)$ dan Papua Barat $(57,1 \%)$

(Pusdatin, 2016).

Menurut data Dinas Kesehatan Provinsi Papua tahun 2017, imunisasi BCG sebanyak 44,484 (62,5\%), Hb0 30,947 (43,5\%), DPT-HBHib1 45,910 (67,5), DPT-HB-Hib3 40,679 (59,8\%), Polio4 41,477 (61,0), Campak/MR1 44,832 (65,9\%), IPV 11,086 (16,3\%), imunisasi dasar lengkap 31,255 (46,0\%).

Menurut data Dinas Kabupaten Jayapura tahun 2016, didapatkan jumlah kelahiran hidup 2.782 (laki-laki 1.421 dan perempuan 1.361) yang imunisasi Hb0 3.251 (laki-laki 1.645 dan perempuan 1.606), BCG 3.654 (laki-laki 1.846 dan perempuan 1.808), DPT-HB3/DPT-HB-Hib3 3.227 (laki-laki 1.664 dan perempuan 1.563), Polio $4^{\mathrm{a}} 3.157$ (laki-laki 1.624 dan perempuan 1.533), Campak 3.104 (laki-laki 1.581 dan perempuan 1.523), imunisasi dasar lengkap 2.5449 (laki-laki 1.304 dan perempuan 1.245).

Data imunisasi di Puskesmas Sentani pada bulan Januari sampai dengan Juli 2018, didapatkan 10.945 anak melakukan imunisasi (Hb0, BCG, Polio1, 2, 3, 4, DPT-Hb1, 2, 3 dan 
Campak), rata-rata perbulan 1.564 anak. Pada bulan Mei 2019 didapatkan data imunisasi pada bayi berjumlah 1.347 mencakup imunisasi $\mathrm{Hb}$, BCG, Polio1, DPT-HB-Hib1, Polio2, DPTHB-

Hib2, Polio3, DPT-HB-Hib3, Polio4, IPV, Campak Rubela (MR) dan imunisasi dasar lengkap. Imunisasi pada batita berjumlah 97 dengan cakupan imunisasi DPT-HB-Hib dan Campak Rubela (MR). Hasil wawancara dengan petugas Kesehatan Ibu dan Anak (KIA) diperoleh data masih ada ibu yang tidak pernah melakukan imunisasi pada anaknya dengan alasan tidak ada uang transportasi, takut anaknya sakit atau panas setelah imunisasi.

\section{METODE PENELITIAN}

Jenis penelitian ini menggunakan jenis penelitian kuantitatif dengan rancangan PraEksperimen (pra-experiments design) dengan One group Pretest-Postest. Rancangan ini tidak disertakan kelompok control (pembanding) dengan pre test dan post test, dengan jumlah populasi 1347 orang dan sampel berjumlah 93 orang.

\section{Analisa Univariat}

a. Karakteristik Responen Ibu

Berjumlah 49 orang (52.7\%), umur 17-25 tahun berjumlah 35 orang $(37.6 \%)$ dan umur 36-45 tahun berjumlah 9 orang $(9.7 \%)$. Karakteristik pendidikan responden paling banyak berpendidikan SMA berjumlah 55 orang (59.1\%), Sarjana berjumlah $\quad 17 \quad$ orang

$$
\text { (18.3\%), SD berjumlah } 10 \quad \text { orang }
$$

(10.8\%), SMP berjumlah 7 orang $(7.5 \%)$ dan tidak bersekolah berjumlah 4 orang (4.3\%). Karakteristik pekerjaan responden paling banyak adalah IRT berjumlah 73 orang (78.5\%), Wiraswasta berjumlah 11 orang (11.8\%), Wiraswasta berjumlah 11 orang (11.8\%), PNS berjumlah 8 orang $(8.6 \%)$,

Petani berjumlah 1 orang $(1.1 \%)$. Berdasarkan karakteristik agama, responden terbanyak beragama Kristen sebanyak 51 orang $(54.8 \%)$ dan beragama Islam sebanyak 42 orang (45.2\%). Dan berdasarkan suku, responden terbanyak adalah suku Non Papua sebanyak 51 orang $(54.8 \%)$ dan suku Papua sebanyak 42 orang $(45.2 \%)$.

b. Karakteristik anak

Kebanyakan ibu-ibu mempunyai anak pertama dengan jumlah 43 orang (46\%) danpaling sedikit adalah anak ke tujuh yaitu
1 orang (1\%) dan anak ke sebelas 1 orang $(1 \%)$. Berdasarkan umur, hasil yang didapatkan ibu-ibu mempunyai anak $<1$ tahun sebanyak 90 orang (97\%) dan paling sedikit berumur $>1$ tahun 3orang (3\%).

c. Pengetahuan Ibu Sebelum Promosi Kesehatan Imunisasi Tingkat pengetahuan responden berada pada kategori baik sebanyak 3 orang (3.2\%), pengetahuan cukup sebanyak 62 orang $(66.7 \%)$ dan pengatuhan kurang sebanyak 28 orang $(30.1 \%)$.

d. Pengetahuan Ibu Sesudah Promosi Kesehatan Imunisasi. tingkat pengetahuan baik sebanyak 47 orang (50.5\%), pengetahuan cukup sebanyak 38 orang (40.9\%) dan pengetahuan kurang sebanyak 8 orang $(8.6 \%)$.

\section{Analisa Bivariat}

Tabel 1 Pengaruh Promosi Kesehatan Imunisasi Pada Anak Usia 0.5 Tahun Terhadap Peningkatan Pengetahuan Ibu

\begin{tabular}{|c|c|c|c|c|c|}
\hline & 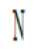 & Mean & Std. Deviasi & $\mathrm{T}$ & p \\
\hline Pre Test & 93 & 59.73 & 9.756 & \multirow{2}{*}{-10.869} & \multirow{2}{*}{0,00} \\
\hline Post Test & 93 & 73.61 & 12.079 & & \\
\hline
\end{tabular}

Berdasarkan tabel 1 di atas menunjukkan nilai t sebesar 10.869 dan signifikansi lebih kecil dari $5 \%(p=0,000<0,05)$. Hal ini menunjukkan bahwa terdapat pengaruh prmosi kesehatan imunisasi pada anak usia 0-5 tahun terhadap peningkatan pengetahuan ibu di Puskesmas Sentani.

\section{PEMBAHASAN}

\section{Karakteristik Responden}

Umur mempengaruhi daya tangkap dan pola pikir seseorang. Semakin bertambahnya umur akan semakin berkembang pula daya tangkap dan pola pikirnya sehingga pengetahuan yang diperoleh semakin baik (Dwi, 2017)

a. Pendidikan Ibu

Pendidikan merupakan sebuah proses pengubahan sikap dan tata laku seseorang atau kelompok dan juga usaha mendewasakan manusia melalui upaya pengajaran dan pelatihan (Rahayu, 2010). Hal ini sejalan degan pendapat 
Notoatmodjo (2012) bahwa semakin tinggi tingkat pengetahuan seseorang, maka akan semakin mudah untuk menerima informasi tentang objek atau yang berkaitan dengan pengetahuan.

b. Pekerjaan Ibu

karakteristik pekerjaan responden yang dominan adalah seorang ibu rumah tangga yaitu sebanyak 48 orang (80\%), ini sangat mendukung dalam ketersediaannya waktu seorang ibu untuk mendengarkan penyuluhan dan membaca leaflet. Adapun hasil penelitian dari Dewi (2016) bahwa sebagian besar responden adalah ibu rumah tangga,dengan pekerjaan menjadi ibu rumah tangga, ibu mempunyai waktu dan perhatian yang cukup untuk status imunisasi bayinya sehingga memungkinkan bayi untuk mendapat imunisasi secara tepat waktu dan lengkap.

c. Agama Ibu

Agama merupakan sesuatu kepercayaan yang dianut oleh seseorang dimana mereka dapat bertindak sesuai dengan yang diajarkan oleh agama, selama tidak bertentangan maka akan dilakukan. Selama imunisasi aman dan tidak mendapatkan larangan dari pihak agama maka orang tua pasti akan membawa anaknya untuk diimunisasi. Dari hasil yang didapatkan yang bergama Islam dan Kristenpun sama- sama membawa anaknya untuk diimunisasi. Jadi Agama seseorang bukan menjadi penghabat untuk melakukan imunisasi.

\section{d. Suku Ibu}

Setiap orang berasal dari suku yang berbeda-beda dan dalam setiap suku mempunyai kebudayaan berserta kebiasaan dalam keluarga dapat mempengaruhi pengetahuan, presepsidan sikap seseorang terhadap sesuatu (Notoatmodjo, 2010). Hal ini sejalan dengan penelitian (Saragih, 2014) bahwa masyarakat Indonesia masih sangat menghargai dan menganggap budaya / adat istiadat sebagai suatu yang tidak boleh diabaikan.

e. Karakteristik Anak

Sejalan dengan penelitian yang dilakukan oleh Nur (2017), menunjukkan responden yang memiliki anak pertama berjumlah 30 orang (42\%) dan yang berkisar 2-3 orang berjumlah 27 orang (38\%). Menurut Nur (2017), ibu-ibuyang mempunyai anak lebih dari satu memiliki riwayat melengkapi imunisasi dasar pada anak sebelumnya. Hasil penelitian yang didapatkan di Puskesmas Sentani, menunjukkan ibu-ibu dengan mayoritas anak pertama belum mempunyai pengalaman yang cukup dalam mengimunisasikan anaknya. Hal ini ditunjukkan dengan lembar kuesioner yang diisi oleh responden dimana pada riwayat imunisasi ibu-ibu tidak mengetahui imunisasi apa yang sudah pernah didapatkan oleh anaknya.

f. Riwayat Imunisasi

Menurut peneliti, ketidaklengkapan imunisasi ada pengaruhnya dengan pengalaman maupun tingkat pendidikan seorang ibu. Ketika seorang ibu sudah mempunyai pengalaman tentangimuniasi maka kedepannya anak berikutnya akan diimunisasi secara lengkap. Dari hasil penelitian yang dilakukan oleh Riska (2015) menyatakan bahwa ketidaklengkapan imunisasi diakibatkan oleh pendidikan yang dimiliki oleh orang tua. Orang tua dengan tingkat pendidikan rendah cenderung tidak melengkapi imunisasi anaknya.

\section{Pengetahuan Ibu Sebelum Promosi}

\section{Kesehatan Tentang Imunisasi}

Sebelum dilakukan promosi kesehatan tentang imunisasi, peneliti melakukan pre test untuk mengetahui tingkat pengetahuan responden. Hasil yang diperoleh pada tabel 4.3. menunjukkan tingkat pengetahuan responden dalam kategori cukup yaitu sebanyak 62 orang $(66.7 \%)$ dan kurang sebanyak 28 orang (30.1\%). Dari hasil penelitian yang didapatkan rata-rata ibu yang mempunyai tingkat pengetahuan yang kurang dikarenakan tidak mengetahui tentang imunisasi Hb0, Hepatitis B, BCG, DPT-HBHib dan campak. Ibu-ibu lebih paham pada imunisasi polio.

Hal ini sejalan dengan penelitianyang dilakukan oleh Veronica (2015), dimana sebelum melakukan penyuluhan tentang imunisasi campak pengetahuan ibu dalam kategori kurang yaitu 43 orang $(71,7 \%)$, kategori cukup sebanyak 12 orang 
(20\%) dan kategori baik 5 orang (8,3\%). Berdasarkan hasil peneltilitan yangdidapatkan di Puskesmas Sentani, sebagian besar adalah anak pertama sehingga dalam hal pengalaman ibu-ibu masih belum tahu tentang imunisasi dan kadang ibu-ibu lupa kapan harus membawa anak untukdiimunisasi.

3. Pengetahuan Ibu Sesudah Promosi

\section{Kesehatan Tentang Imunisasi}

Sesudah dilakukan perlakuan dengan memberikan promosi kesehatan tentang imunisasi, peneliti melakukan post test untuk mengetahui apakah ada perbedaan tingkat pengetahuan responden sebelum dan sesudah dilakukan promosi kesehatan. Dari tabel 4.4. menunjukkan hasil post test tingkat pengetahuan responden dalam kategori baik sebanyak 47 orang (50.5\%). Berdasarkan hasil penelitian yang ditemukandi Puskesmas Sentani, menunjukkan bahwa terjadinya perubahan pengetahuan ibu sesudah diberikan promosi kesehatan dimana sebagian besar dapat menjawab dengan skor jawaban benar 25-32 soal (>76-100\%).

4. Pengaruh Promosi Kesehatan Imunisasi Terhadap Peningkatan Pengetahuan Ibu

Dari hasil penelitian yang dianalisis menggunakan uji paired sample T-Test sebesar -10.869 sehingga bisa diambil kesimpulan untuk menerima $\mathrm{H}_{\mathrm{a}}$ karena pvalue $<\alpha$ yaitu $0,000<0,05$. Dengan demikian hipotesis yang menyatakan bahwa promosi kesehatan tentang imunisasi pada anak usia 0-5 tahun berpengaruh terhadap peningkatan pengetahuan Ibu di Puskesmas Sentani. Maka dapat disimpulkan dengan pemberian promosi kesehatan tentang

Imunisasi Dasar Dengan Kelengkapan Imunisasi Dasar Bayi Di Wilayah Kerja Puskesmas Bendo Kabupaten Magetan. 8(2): 10

Donsu, Jenita Doli Tine. (2016). Metodologi Penelitian Keperawatan. Yogyakarta: Pustakabarupres

Dwi, H.E., Erindra, B.C, \& Mujahidatul, M. (2017). Pengaruh Penyuluhan Terhadap Pengetahuan Ibu Tentang Imunisasi Pentavalen Lanjutan Pada Batita Di Kelurahan Keprabon Surakarta. Jurnal Edumidwifery, 1(2): 73. imunisasi dapat mempengaruhi tingkat pengetahuan ibu sehingga dengan pengetahuan yang diperoleh ibu datang membawa anaknya untuk diimunisasi.

\section{KESIMPULAN}

Dari keseluruhan proses penyelesaian penelitian ini yang mencakup pengumpulan data dan melakukan promosi kesehatan tentang imunisasi yang dilakukan di Puskesmas Sentani, didapatkan kesimpulan penelitian bahwa promosi kesehatan tentang imunisasi pada anak usia 0-5 tahun berpengaruh terhadap peningkatan pengetahuan Ibu di Puskesmas Sentani. Dinyatakan berpengaruh berdasarkan hasil uji paired sample T-Test tyang menunjukkan adanya perbedaan peningkatan pengetahuan ibu tentang imunisasi dan didukung oleh nilai $p$ value yaitu 0,000 sehingga promosi kesehatan merupakan salah satu cara yang efektif untuk menyebarkan informasi. Informasi diberikan kepada ibu-ibu agar dimengerti sehingga mereka dapat membawa anaknya untuk diimunisasi.

\section{DAFTAR PUSTAKA}

Arikunto, Suharsimi. (2010). Prosedur Penelitian : Suatu Pendekatan Praktik. Jakarta: Rineka Cipta

Cecilia, T., Ellen, P., \& Dionysius, S. (2017). Pengaruh Promosi Kesehatan Tentang HIV/AIDS Terhadap Tingkat Pengetahuan Remaja. 4(1): (6-7) Dewi, N.S., Sri, W.B, N., Juni,T. (2016). Hubungan Pengetahuan Ibu Tentang

Imas, M. \& Nauti, A.T. (2018). Metodologi Penelitian Kesehatan.

Imron, M., \& Munif, A. (2010). Metodologi Penelitian Bidang Kesehatan. Jakarta: Sagung Seto

Ircham, M. (2009). Metodologi Penelitian. Yogyakarta: Fitramaya

Kemenkes RI. (2011). Promosi Kesehatan di Daerah Bermasalah Kesehatan. Panduan Bagi Petugas Kesehatan di Puskesmas. Jakarta: Kemenkes RI

Kemenkes RI. (2017). Profil Kesehatan Indonesia Tahun 2016. Jakarta: Kemenkes 
RI

Kian Santang. (2018). Peran Perawat Dalam Promosi Kesehatan di https://www.scribd.com/document/37298 9214/Peran-Perawat-Dalam Promos- docx. Di akses tanggal 24 Agustus 2018

Mubarak. W. I. (2011). Promosi Kesehatan. Jogjakarta: Graha Ilmu

Notoatmodjo, S. (2012). Pendidikan Dan Perilaku Kesehatan. Jakarta: Rineka Cipta Notoatmodjo, S. (2014). Metodologi Penelitian Kesehatan. Jakarta: Rineka Cipta Nurhidayati. (2016). Hubungan Pengetahuan Ibu Tentang Imunisasi Dasar di Wilayah Kerja Puskesmas Pisangan Tangerang. Jakarta. Fakults Kedokteran dan Ilmu Kesehatan.

Nurul, H., Hetty, M.S., Wanda, L. (2017). Faktor Yang Berhubungan Dengan Pemberian Imunisasi Dasar Lengkap Pada Bayi. Jurnal Endurance, 153161)

Nur, D., dkk. Buku Ajar Imunisasi. Jakarta: Pusat Pendidikan dan Pelatihan Tenaga Kesehatan; 2015

Pemerintah Indonesia. (2014). UndangUndang No. 38 Tahun 2014 Tentang Keperawatan. Lembar Negara RI

Pusdatin. (2016). Situasi Imunisasi di Indonesia. Jakarta

Sinta. (2011). Promosi Kesehatan. Yogyakarta: Graha Ilmu

Siti, Rismalinda, dkk. (2010). Buku Saku Metodologi Penelitian Untukn Mahasiswa Diploma Kesehatan. Jakarta : TIM

Sujarweni, V. W. (2014). Metode Penelitian : Lengkap, Praktis, dan Mudah Dipahami. Yogyakarta: Pustaka Baru Press

Undang-Undang Keperawatan Nomor 38 Tahun2014 Tentang Kesehatan.

http://www.hukor.depkes.go.id/?doku me $\quad \mathrm{n}=$ global\&type $=1 \& \mathrm{th}=2014$. Diakses: 24

Agustus 2018

Veronica, F.B., Meildy, E.P., \& Freike, L. (2015). Pengaruh Penyuluhan Imunisasi Campak Terhadap Peningkatan Pengetahuan Dan Sikap Ibu. Jurnal Ilmiah Bidan. 3(2): 48
Wawan, A. dan Dewi, M. (2010). Teori dan Pengukuran Pengetahuan, Sikap dan Perilaku Manusia. Yogyakarta : Nuha Medika 